\title{
ACCUMULATION OF PURINE AND PYRIMIDINE DERIVATIVES BY MICROORGANISMS
}

\section{ISOLATION AND CHARACTERIZATION OF A MUTANT DEVOID OF $5^{\prime}$-NUCLEOTIDE-DEGRADING ABILITY DERIVED FROM AN ADENINE AUXOTROPH OF BACILLUS SUBTILIS 209-4}

\author{
MITSUHIKO FUJIWARA, VLADIMIR BYHOVSKY,* HIROAKI NAKAMURA, \\ GAKUZO TAMURA AND KEI ARIMA \\ Department of Microbiology and Fermentation, University of Tokyo, \\ 1-1-1, Yayoi-cho, Bunkyo-ku, Tokyo, Japan, \\ and \\ Institute of Biochemistry, Academy of Sciences of U.S.S.R.,* \\ 33, Leninskii Prospekt, Moscow, U.S.S.R.
}

(Received October 25, 1966)

\begin{abstract}
A mutant strain No. 6, devoid of $5^{\prime}$-nucleotide-degrading ability, was derived from adenine auxotrophic strain No. 93 originating from Bacillus subtilis 209-4, and the accumulation of 5 -IMP under various conditions was examined.

In No. 6, the early stage of growth was inhibited in the presence of more than $500 \mu \mathrm{g} / \mathrm{ml}$ of adenine, whereas the duration of the maximum growth was maintained only shortly followed by a marked lysis in the presence of less than $180 \mu \mathrm{g} / \mathrm{ml}$ of adenine. On the other hand, such phenomenon was not observed at all in the case of the adenineless mutant No. 93. Such a characteristic response to adenine in the mutant devoid of $5^{\prime}$-nucleotide-degrading ability seems to be related with activity of phosphatase (5'-nucleotidase or alkaline phosphatase) in cells.

The mechanism of the accumulation of the purine and pyrimidine derivatives by No. 6 was also influenced by the adenine content in the medium. When $100 \mu \mathrm{g} / \mathrm{ml}$ of adenine was added to the culture, nucleotides accumulated as the result of the degradation of cellular RNA. On the other hand, when more than $180 \mu \mathrm{g} / \mathrm{ml}$ of the adenine was present, mostly inosine was accumulated in medium; this was considered to be synthesized de novo by viable cells.
\end{abstract}

In the industrial production of purine and pyrimidine derivatives by microorganism (1-28), the accumulation in a large amount of $5^{\prime}$-nucleotides of any applicable value is required. In our previous papers (22-24) is described the excretion of purine and pyrimidine derivatives by microorganisms, such as bacteria, yeasts and fungi, both prototrophs and auxotrophs requiring 
vitamins, amino acids, purines and pyrimidines, with special reference to the quantitative aspects of these products. We described that an adenineless mutant strain No. 93 derived from Bacillus subtilis 209-4 excreted a large amount of inosine $(\mathrm{HxR})$ even as high as $5 \mathrm{~g}$ inosine per liter of medium. Such an accumulation of nucleosides was suggested to be caused by the decomposition of formed nucleotides by nucleotidase.

In the present investigation, our attention was focused on the isolation of a mutant devoid of $5^{\prime}$-nucleotide-degrading ability. Results showed that such a mutant derived from the inosine-producing strain No. 93 formed 50 $\mu \mathrm{g} / \mathrm{ml}$ of $5^{\prime}$-inosinic acid $\left(5^{\prime}\right.$-IMP).

\section{MATERIALS AND METHODS}

Organisms. Bacillus subtilis 209-4 obtained from the type culture collection of this Department was irradiated with ultraviolet ray and adenine auxotrophs were detected by the replica plating (29). An adenineless mutant, No. 93, which excreted inosine was subjected to further mutation by the same technique.

Media. The slant medium for maintenance of the mutants contained the followings per liter: glucose, $30 \mathrm{~g}$; casamino acid, $20 \mathrm{~g}$; yeast autolysate, $5 \mathrm{~g} ; \mathrm{K}_{2} \mathrm{HPO}_{4}, 3 \mathrm{~g} ; \mathrm{KH}_{2} \mathrm{PO}_{4}, 1 \mathrm{~g} ; \mathrm{MgSO}_{4} \cdot 7 \mathrm{H}_{2} \mathrm{O}, 0.2 \mathrm{~g}$; adenine sulfate, $0.1 \mathrm{~g}$; and agar, $20 \mathrm{~g}$. The complete medium (C-medium) for the isolation of mutant devoid of $5^{\prime}$-nucleotide-degrading ability were composed of the following components per liter: glucose, $10 \mathrm{~g}$; casamino acid (Difco, vitamin-free), $10 \mathrm{~g}$; $\mathrm{NH}_{4} \mathrm{Cl}, 5 \mathrm{~g} ; \mathrm{NH}_{4} \mathrm{NO}_{3}, 1 \mathrm{~g} ; \mathrm{Na}_{2} \mathrm{SO}_{4}, 2 \mathrm{~g} ; \mathrm{K}_{2} \mathrm{HPO}_{4}, 3 \mathrm{~g} ; \mathrm{KH}_{2} \mathrm{PO}_{4}, 1 \mathrm{~g} ; \mathrm{MgSO}_{4}$. $7 \mathrm{H}_{2} \mathrm{O}, 0.1 \mathrm{~g}$; adenine sulfate, $0.05 \mathrm{~g}$. The minimal medium (M-medium) used for the same purpose was the same as the C-medium except that $0.1 \mathrm{~g}$ of $5^{\prime}$-adenylic acid $\left(5^{\prime}\right.$-AMP) was substituted for $0.05 \mathrm{~g}$ of adenine sulfate. For the preparation of the latter medium, $5^{\prime}$-AMP was sterilized separately by means of Seitz filtration and added to the sterilized medium devoid of adenine. The production medium (P-medium) used for the production of $5^{\prime}$-nucleotides contained the following components: glucose, $50 \mathrm{~g}$; polypeptone, $20 \mathrm{~g}$; yeast autolysate, $3 \mathrm{~g} ; \mathrm{NaHCO}_{3}, 5 \mathrm{~g} ; \mathrm{K}_{2} \mathrm{HPO}_{4}, 6 \mathrm{~g} ; \mathrm{KH}_{2} \mathrm{PO}_{4}, 2 \mathrm{~g} ; \mathrm{MgSO}_{4} \cdot 7 \mathrm{H}_{2} \mathrm{O}, 0.2 \mathrm{~g}$; adenine sulfate, $0.05 \mathrm{~g}$; and water to 1 liter ( $\mathrm{pH} 6.8$ ).

Procedure for isolation of mutants. Mutants were isolated principally by the methods of FUjimoto et al. (31). Spores of the adenine auxotroph No. 93 suspended in physiological saline were irradiated with ultraviolet ray ("National" brand sterilizing lamp, $19 \mathrm{~W}$, at $40 \mathrm{~cm}$, for $7 \mathrm{~min}$ ). After the replica plating, colonies grown on adenine but not at all or only slightly on $5^{\prime}$-AMP were isolated.

Condition for the fermentation. The mutants were transferred to test tubes $(21 \mathrm{~mm}$ in diameter) containing $10 \mathrm{ml}$ of P-medium. These test tubes were incubated on a shaking machine at $30^{\circ}$ for 3 days.

Paper chromatography. Paper chromatographic examination of the 
broth was performed using Toyo No. 53 filter paper. Solvent systems employed were: (A) butanol-acetic acid-water (2:1:1) (32); (B) butanol-ammonium hydroxide-water (200:2.5:35); (C) methanol-ethanol-hydrochloric acid-water $(25: 50: 6: 19)$. After the development and drying of the chromatograms, intensities of the bands were estimated by examination under ultraviolet ray (Manaslu-light). Cochromatography with authentic samples was performed for the identification of each band.

Paper electrophoresis. Paper electrophoresis was carried out on Toyo No. 53 filter paper used $10 \%$ acetic acid as solvent at a constant voltage of $500 \mathrm{~V}$ for 4 to $6 \mathrm{hr}$.

Column chromatography. The supernatant of cultured broth $(3-4 \mathrm{ml})$ of $\mathrm{pH} 9.6$ was chromatographed on a Dowex-1X4 or X8 column (100 to 200 mesh, formate form, $7 \times 1.4 \mathrm{~cm}$ ) at the rate of $30 \mathrm{ml} / \mathrm{hr}$. The gradient elution with 0.1 to $2 \mathrm{~N}$ ammonium formate was performed. Ultraviolet absorbance at $253 \mathrm{~m} \mu$ of each fraction was recorded by a Uvicord (LKB type 4701, Sweden). Identification of the main fractions were performed by paper chromatography after concentration by charcoal adsorption, elution with ethanolammonium hydroxide-water $(5: 3: 2)$ and evaporation in vacuo.

Quantitative estimation of purine and pyrimidine derivatives. An aliquot $(0.05 \mathrm{ml})$ of the supernatant of the culture was developed on a filter paper and each spot was extracted with $0.1 \mathrm{~N}$ hydrochloric acid at $37^{\circ}$ for $12 \mathrm{hr}$ and the ultraviolet absorbance at $260 \mathrm{~m} \mu$ was measured.

Measurement of $5^{\prime}$-nucleotide-degrading activity. The culture filtrate was dialyzed against water for $6 \mathrm{hr}$ at $4^{\circ}$ and its activity of degrading $5^{\prime}$ IMP was examined. The reaction mixture contained $1 \mathrm{ml}$ of the dialyzed culture filtrate or washed cell suspension $(10 \mathrm{mg}$ of cells in dry weight), $2 \mathrm{ml}$ of sodium Veronal-sodium acetate buffer $(\mathrm{pH} 7)$ or $1 / 5 \mathrm{M}$ Tris buffer $(\mathrm{pH} 8.6)$, $1 \mathrm{ml}$ of $5^{\prime}$-IMP $(40 \mathrm{mM})$. The mixture was incubated at $37^{\circ}$ for $1 \mathrm{hr}$ and inorganic phosphate liberated was determined by NAKAMURA's method (33).

\section{RESULTS}

Isolation of mutants less active in degrading $5^{\prime}$-nucleotides

Fifty-seven colonies grown on adenine but not at all or only slightly on $5^{\prime}$-AMP were isolated after UV-irradiation of the adenine auxotroph No. 93 and were incubated at $30^{\circ}$ for 3 days in the P-medium. Paper chromatogram using solvent systems $\mathrm{A}$ and $\mathrm{B}$ of the culture broths indicated three different bands, $a, b$, and $c$ (Fig. 1). Bands $b$ and $c$ were identified to be inosine and hypoxanthine $(\mathrm{Hx})$, respectively. An examination of band $a$ by electrophoresis revealed that substances contained in the band were composed of five components. These substances were considered to be nucleotides as judged from their mobility on paper chromatogram. 


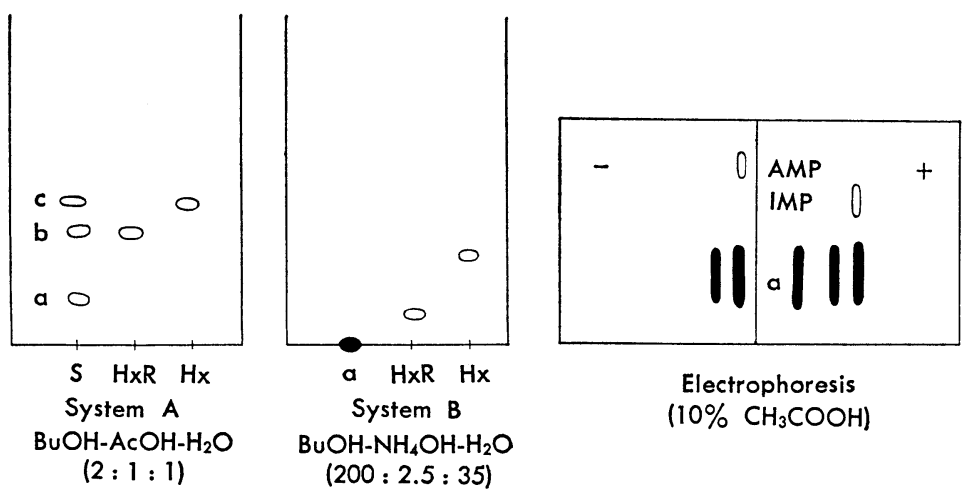

Fig. 1. Purine-pyrimidine derivatives accumulated by mutants less active or inactive in $5^{\prime}$-nucleotide degradation.

All mutant strains were cultured for 3 days at $30^{\circ}$ in P-medium $(10 \mathrm{ml})$ contained in test tubes $(21 \mathrm{~mm}$ diam. $)$ Later, for the repeated culture test of the mutants, yeast autolysate was omitted from the P-medium.

S : Sample (culture filtrate).

Spot a: Mixture of nucleotides.

Spot b: Inosine $(\mathrm{HxR})$.

Spot c: Hypoxanthine $(\mathrm{Hx})$.

\section{5'-Nucleotide-degrading activity of the mutants}

(A) Activities of dialyzed culture media. All the 57 mutant strains were classified into 6 groups according to the pattern of chromatogram of culture media. Employing several mutant strains selected from these groups, supernatants of culture media were examined for (1) 5'-IMP-decomposing activity and (2) amounts of UV-absorbing substances (Table 1). The strain No. 93, the parent strain, produced inosine together with a small amount of hypoxanthine and the culture supernatant exhibited a strong 5'-IMP-decomposing activity, whereas the culture supernatants of strains belonging to Group 1 exhibited the enzyme activity only slightly and those of strains No. 6, No. 49 , and No. 55 not at all. The substances excreted by Group 1 strains were nucleotides only. By contrast, either inosine or hypoxanthine was excreted by strains of the other groups which had much higher level of $5^{\prime}$-nucleotidedegrading activity than the Group 1.

(B) Activity of intact cells. 5'-IMP-decomposing activity of the washed cells of strains No. 93 and No. 6 suspended in buffer of different pH's was examined (Fig. 2). Although the culture supernatant of No. 6 showed almost no activity of $5^{\prime}$-nucleotide degradation, the washed cells of this strain showed an appreciable activity as high as approximately one-third of those of the parent strain. This mutant strain also hydrolyzed $p$-nitrophenyl phosphate $(p-\mathrm{NPP})$; optimum $\mathrm{pH}$ being in the range of $8-9$. 
Table 1. 5'-IMP-decomposing activity of the dialyzed culture filtrate of mutants

\begin{tabular}{|c|c|c|c|c|c|c|c|}
\hline \multirow{3}{*}{$\begin{array}{l}\text { Group } \\
\text { No. }\end{array}$} & \multirow{3}{*}{$\begin{array}{l}\text { Strain } \\
\text { No. }\end{array}$} & \multirow{3}{*}{$\begin{array}{l}\mathrm{OD}_{260} / \mathrm{ml} \\
\text { of culture } \\
\text { filtrate }\end{array}$} & \multirow{3}{*}{$\begin{array}{l}\text { Cell dry } \\
\text { wt. mg/ } \\
10 \mathrm{ml}\end{array}$} & \multicolumn{3}{|c|}{ UV-absorbing substances ${ }^{a}$} & \multirow{3}{*}{$\begin{array}{l}\text { Amount of } \\
\mathrm{P}_{i} \text { liberated } \\
\quad(\mu \text { moles })\end{array}$} \\
\hline & & & & \multicolumn{3}{|c|}{ Spot } & \\
\hline & & & & $a$ & $b$ & $c$ & \\
\hline \multirow{7}{*}{ I } & 93 & 153 & 38 & $<0.1$ & 84.5 & 15 & 3.75 \\
\hline & 6 & 86 & 22 & 11.5 & $<0.1$ & $<0.1$ & $<0$ \\
\hline & 19 & 72 & 29 & 7.0 & $<0.1$ & $<0.1$ & 0.56 \\
\hline & 28 & 62 & 31 & 6.5 & $<0.1$ & $<0.1$ & 0.19 \\
\hline & 37 & 83 & 39 & 5.0 & $<0.1$ & $<0.1$ & 0.38 \\
\hline & 49 & 85 & 28 & 10.5 & $<0.1$ & $<0.1$ & $<0$ \\
\hline & 55 & 102 & 31 & 8.0 & $<0.1$ & $<0.1$ & $<0$ \\
\hline \multirow[t]{2}{*}{ II } & 54 & 90 & 66 & $<0.1$ & 25 & $<0.1$ & 3.75 \\
\hline & 57 & 162 & 57 & $<0.1$ & 74 & $<0.1$ & 3.40 \\
\hline \multirow{2}{*}{ III } & 30 & 109 & 31 & 3.0 & 28 & $<0.1$ & 4.56 \\
\hline & 34 & 104 & 55 & 4.5 & 25 & $<0.1$ & $<0$ \\
\hline \multirow{2}{*}{ IV } & 1 & 122 & 29 & $<0.1$ & 39.5 & 16.5 & 2.25 \\
\hline & 2 & 153 & 37 & $<0.1$ & 64.5 & 18.5 & 4.2 \\
\hline $\mathrm{V}$ & 26 & 150 & 18 & 4.5 & 62.5 & 13.0 & 2.25 \\
\hline VI & 25 & 104 & 44 & $<0.1$ & $<0.1$ & $<0.1$ & 0.19 \\
\hline
\end{tabular}

a Culture filtrate was subjected to quantitative chromatography (for method see text). Spots $a, b$ and $c$ represent nucleotide-mixture, inosine and hypoxanthine, respectively.

$b$ Reaction mixture contained $1 \mathrm{ml}$ of dialyzed culture filtrate (for $6 \mathrm{hr}$ at $4^{\circ}$ against water), $2 \mathrm{ml}$ of sodium Veronal-sodium acetate buffer $(\mathrm{pH} 7), 1 \mathrm{ml}$ of $5^{\prime}$-IMP $(40 \mathrm{~mm})$, and incubated for $1 \mathrm{hr}$ at $37^{\circ}$.

Strains No. 93 and No. 6 were cultured in high-phosphate $(1 \mathrm{mg} / \mathrm{ml}$ of $\mathrm{KH}_{2} \mathrm{PO}_{4}$ in modified $\mathrm{P}$-medium) and low-phosphate $\left(2 \mu \mathrm{g} / \mathrm{ml}\right.$ of $\left.\mathrm{KH}_{2} \mathrm{PO}_{4}\right)$ media for 3 days at $30^{\circ}$ and the degradation of $5^{\prime}$-IMP $(2 \mathrm{mg} / \mathrm{ml})$ during the cultivation was examined (Table 2). Table 2 shows that No. 6 decomposed 5'IMP completely in the low-phosphate medium but not at all in the highphosphate medium. On the other hand, No. 93 decomposed 5'-IMP completely in both media.

It was reported that the activity of $5^{\prime}$-nucleotide-degradation in Bacillus subtilis was demonstrated in the presence of $1 \mathrm{mg} / \mathrm{ml}$ of phosphate but that of alkaline phosphatase was repressed almost completely under the same condition (30). In our studies, $5^{\prime}$-nucleotide-degrading activity in No. 6 showing $\mathrm{pH}$ optimum at 8-9 was completely inhibited by $1 \mathrm{mg} / \mathrm{ml}$ of phosphate and $p$-NPP was also decomposed by this strain. These facts suggest that 


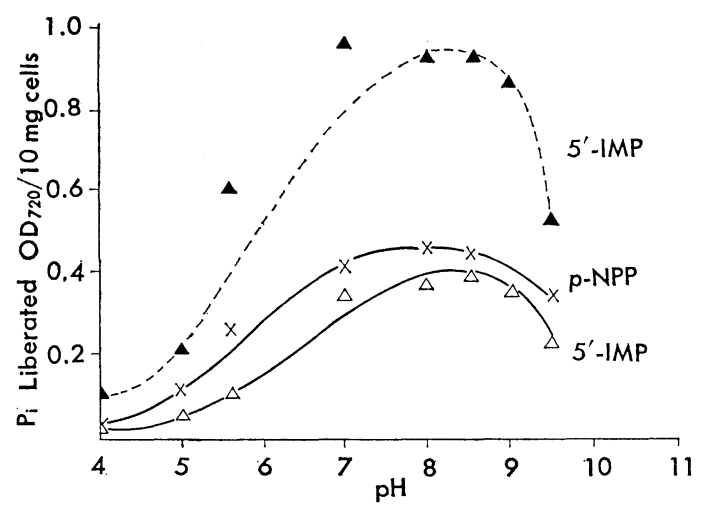

Fig. 2. Influence of $\mathrm{pH}$ on the $5^{\prime}$-IMP-decomposing activity by the washed cell suspension of No. 6 and No. 93 .

No. 6 and No. 93 were incubated for 3 days at $30^{\circ}$ in Pmedium. The cells were collected and washed several times with distilled water by centrifugation. The reaction mixture contained $1 \mathrm{ml}$ of the washed cell suspension, $2 \mathrm{ml}$ of buffer solution of varied $\mathrm{pH}, 1 \mathrm{ml}$ of $5^{\prime}$-IMP $(40 \mathrm{mM})$ or $p$-nitrophenyl phosphate, and was incubated at $37^{\circ}$. Inorganic phosphate liberated was determined by NAKAmURA's method (33).

\section{- Strain No. 6}

.... Strain No. 93

Table 2. Percentage decomposition of $5^{\prime}$-IMP during the cultivation of No. 6 and No. 93 .

\begin{tabular}{c|c|c}
\hline Strain No. & Low phosphate & High phosphate $^{a}$ \\
\hline 93 & 100 & 100 \\
6 & 100 & $<0.1$ \\
\hline
\end{tabular}

a Low and high phosphate media represent modified P-media containing 2 and $1,000 \mu \mathrm{g} \mathrm{KH}_{2} \mathrm{PO}_{4} / \mathrm{ml}$ respectively. The strain Nos. 93 and 6 were incubated at $30^{\circ}$. After $24 \mathrm{hr}$ of incubation, $2 \mathrm{mg} / \mathrm{ml}$ of $5^{\prime}$-IMP was added to each culture and at the end of subsequent 3 days of incubation with $5^{\prime}$-IMP, amount of $5^{\prime}$ IMP in the medium was estimated by the quantitative paper chromatography.

the $5^{\prime}$-nucleotide-degrading activity in No. 6 is exhibited by alkaline phosphatase.

Effect of adenine on the accumulation of purine and pyrimidine derivatives

As shown in Fig. 3, the addition of $50 \mu \mathrm{g} / \mathrm{ml}$ of adenine sulfate effected maximal accumulation of UV-absorbing materials by No. 93, but higher amount of adenine (more than $100 \mu \mathrm{g} / \mathrm{ml}$ ) for the same effect was required 


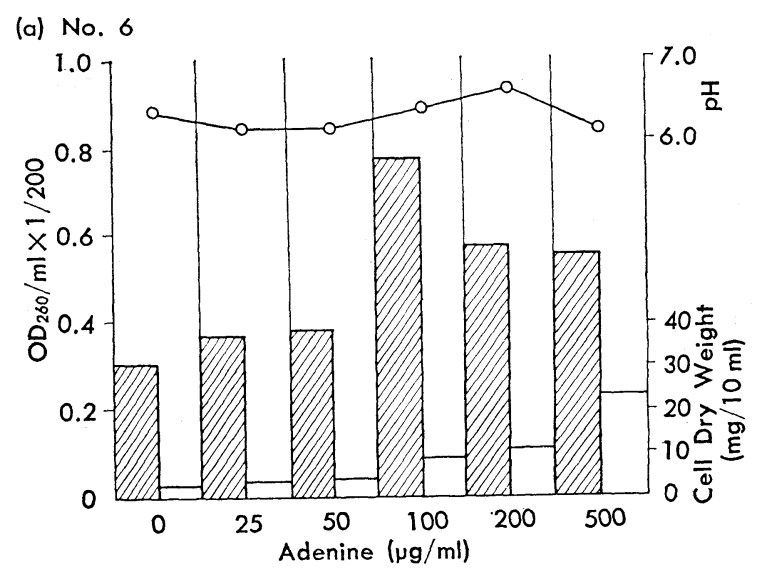

(b) No. 93

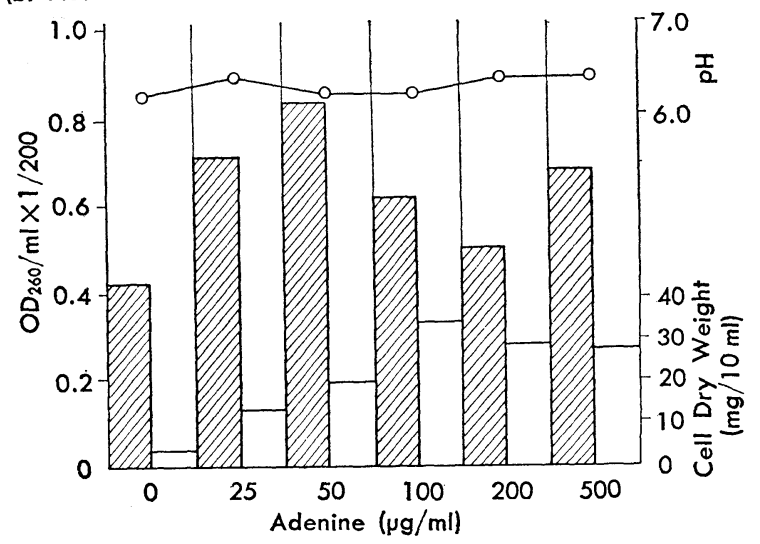

Fig. 3. Effect of adenine on the accumulation of UVabsorbing substances and on growth of No. 6 and No. 93 .

Ultraviolet absorbancy of the broth.

Cell weight as the dry matter $/ 10 \mathrm{ml}$ of the culture.

$\mathrm{O}-\mathrm{O} \mathrm{pH}$ of the broth after 3 days of incubation.

by No. 6. Further observation of the effect of adenine on the accumulation (Fig. 4) revealed that in strains No. 6 and 55 the addition of $180 \mu \mathrm{g} / \mathrm{ml}$ was required for the maximum accumulation; this amount was even 3 to 4 times higher than that found in the parent strain (No. 93).

Growth response of mutants to adenine and $5^{\prime}-A M P$

The growth response of Nos. 93 and 6 to adenine and 5'-AMP was examined (Fig. 5). 5'-AMP supported the growth of No. 93 in the presence of a high concentration of phosphate, although the lag period was prolonged 


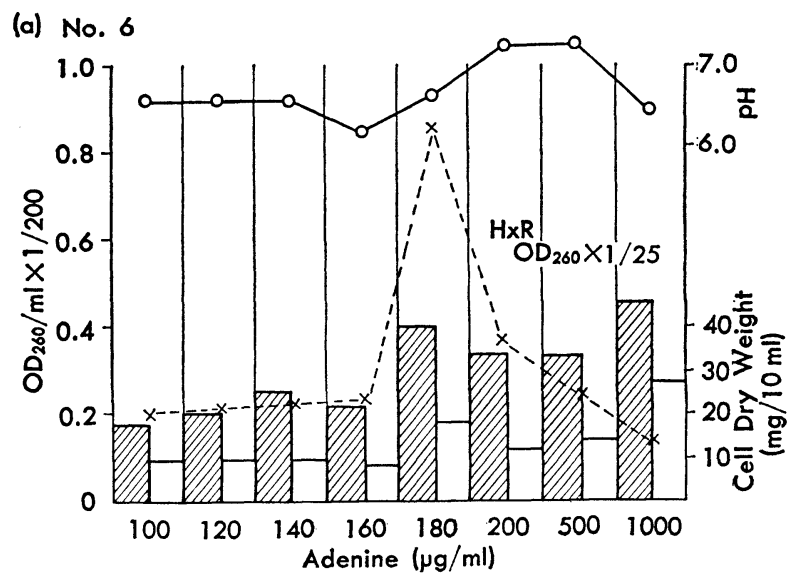

(b) No. 55

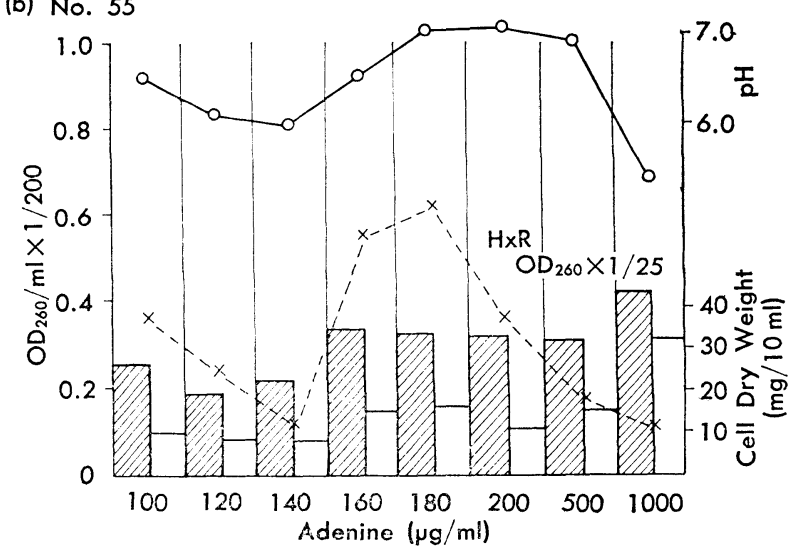

Fig. 4. Effect of adenine on the accumulation of UV-absorbing substances and on growth of mutants devoid of $5^{\prime}$-nucleotidedegrading ability.

Ultraviolet absorbancy of the broth.

$\square \quad$ Cell weight as the dry matter/10 $\mathrm{ml}$ of the culture.

$\bigcirc-\mathrm{pH}$ of the broth after 3 days of incubation.

$\times---\times U V$ absorbance of inosine in the broth (for method see text).

a little more than in medium supplemented with adenine. The growth of No. 93 in 100 to $1,000 \mu \mathrm{g} / \mathrm{ml}$ of $5^{\prime}$-AMP reached the maximum after about $50 \mathrm{hr}$. On the other hand, 100 and $180 \mu \mathrm{g} / \mathrm{ml}$ of $5^{\prime}$-AMP failed to support the growth of No. 6. The growth of No. 6 in either medium containing 100 or $180 \mu \mathrm{g} / \mathrm{ml}$ of adenine reached the maximum until $20 \mathrm{hr}$ and a marked decline followed. When adenine was added at the concentration of either 180 or $100 \mu \mathrm{g} / \mathrm{ml}$ of medium, cells inoculated at the density of $5 \times 10^{2}$ cells $/ \mathrm{ml}$ increased 


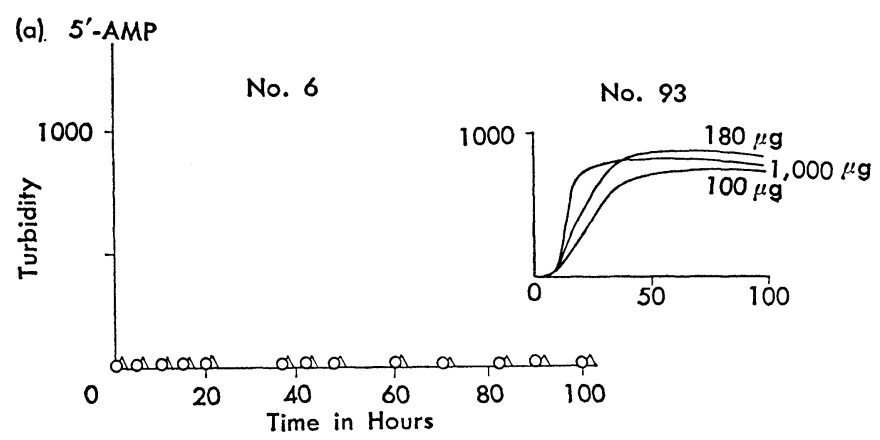

(b) Adenine

No. 93

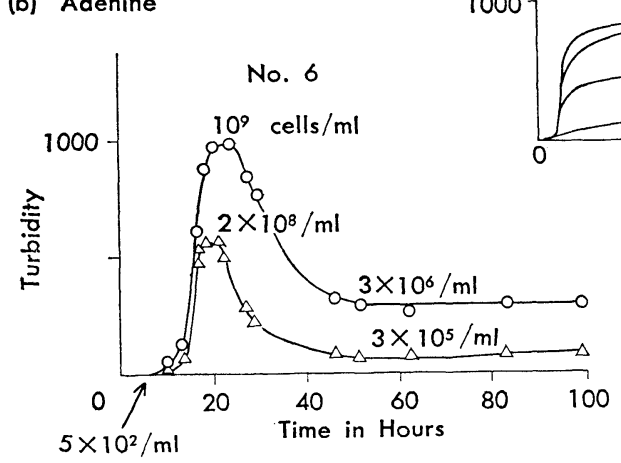

Fig. 5. Growth response of strain Nos. 6 and 93 to $5^{\prime}$-AMP and adenine.

$$
\bigcirc-\bigcirc 180 \mu \mathrm{g} / \mathrm{ml} \quad \Delta-\Delta 100 \mu \mathrm{g} / \mathrm{ml}
$$

up to $10^{9}$ and $2 \times 10^{8}$ cells $/ \mathrm{ml}$, respectively, after $20 \mathrm{hr}$ of incubation. After the subsequent 20 -hr period of incubation, about $99.9 \%$ of the viable cells at the time of the maximal growth underwent lysis. However, in the case of No. 93, the autolysis never occurred even when grown in the presence of low concentration $(10 \mu \mathrm{g} / \mathrm{ml})$ of adenine.

The growth response of No. 6 to high levels of adenine is shown in Fig. 6. As seen in the figure the course of growth of No. 6 as influenced by the intermittent additions of $100 \mu \mathrm{g} / \mathrm{ml}$ of adenine was characteristic. Two repetitions of growth followed by lysis were observed and finally no lysis occurred. When grown in the presence of much higher concentrations of adenine, such as 500 to $1,000 \mu \mathrm{g} / \mathrm{ml}$, the lag period of the growth of No. 6 was largely prolonged but not in No. 93 .

No. 6 was cultivated in $50 \mathrm{ml}$ of a medium containing 100 or $180 \mu \mathrm{g} / \mathrm{ml}$ of adenine and the relationship between the excretion of UV-absorbing substances and the decomposition of cellular RNA was studied (Fig. 7). RNA 

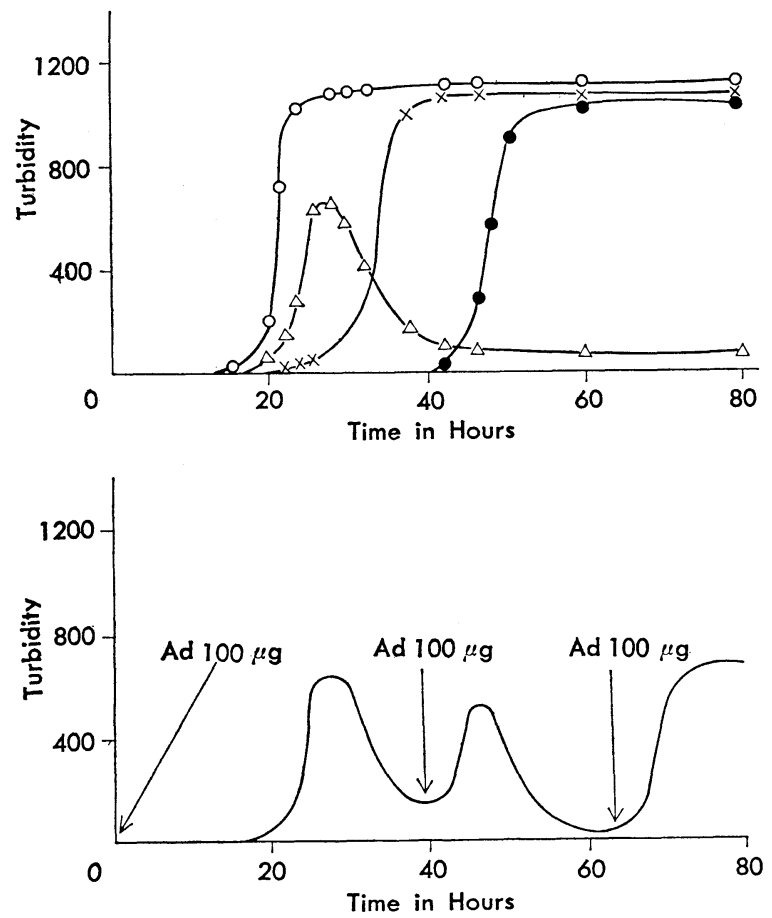

Fig. 6. Influence of adenine on the growth of strain No. 6 .

- Adenine $1000 \mu \mathrm{g} / \mathrm{ml}$ $\times-\times$ Adenine $500 \mu \mathrm{g} / \mathrm{ml}$. Adenine $300 \mu \mathrm{g} / \mathrm{ml}$. $\quad \triangle-\triangle$ Adenine $100 \mu \mathrm{g} / \mathrm{ml}$.

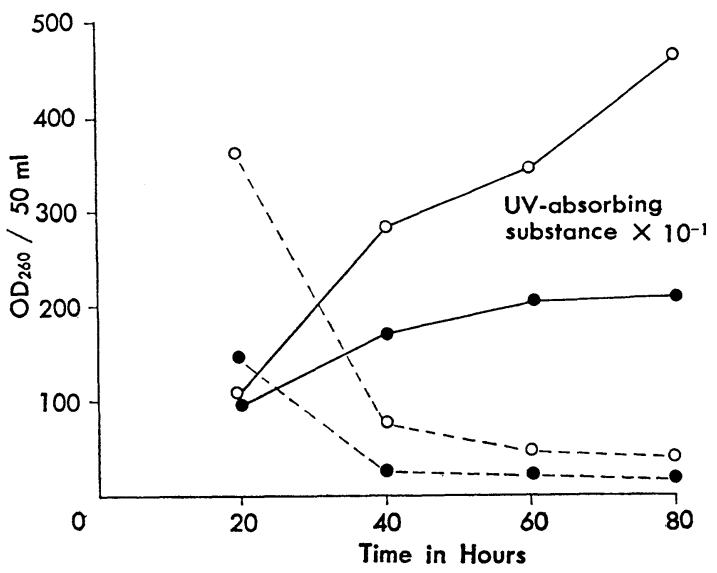

Fig. 7. Relationship between the excretion of UV-absorbing substance and the decomposition of cellular RNA during the growth of No. 6.

○ $180 \mu \mathrm{g} / \mathrm{ml}$ of adenine

- UV-absorbing substance excreted.

$100 \mu \mathrm{g} / \mathrm{ml}$ of adenine -. RNA decomposed. 
was extracted by the method of Schmidt, Thannhauser and Schneider. Fig. 7 shows the courses of change in optical density at $260 \mathrm{~m} \mu$ of cellular RNA and culture medium during cultivation. In general, after $20 \mathrm{hr}$ of incubation, when the growth of No. 6 reached the maximum, RNA decreased markedly during the subsequent $20-\mathrm{hr}$ period of incubation in parallel with an apparent cell lysis. It should be noticed that in the presence of $180 \mu \mathrm{g} /$ $\mathrm{ml}$ of adenine, accumulation of UV-absorbing substances continued after 60 $\mathrm{hr}$ of cultivation when the degradation of RNA had already ceased. This was not observed in the presence of $100 \mu \mathrm{g} / \mathrm{ml}$ of adenine.

Isolation and identification of the purine and pyrimidine derivatives accumulated in the broth of No. 6

Figs. 8 and 9 indicate the elution pattern of the purine and pyrimidine derivatives accumulated in the broth of No. 6, which was grown on $100 \mu \mathrm{g} /$ $\mathrm{ml}$ (Fig. 8) and on $180 \mu \mathrm{g} / \mathrm{ml}$ (Fig. 9) of adenine. When No. 6 was cultivated in the presence of $100 \mu \mathrm{g} / \mathrm{ml}$ of adenine (Fig. 8), the UV-absorbing materials were excreted mostly in the form of nucleotides accompanied with only a small amount of inosine. By contrast, in the presence of $180 \mu \mathrm{g} / \mathrm{ml}$ of adenine (Fig. 9), a greater part of the UV-absorbing materials was occupied mostly by inosine, while the nucleotides were scanty.

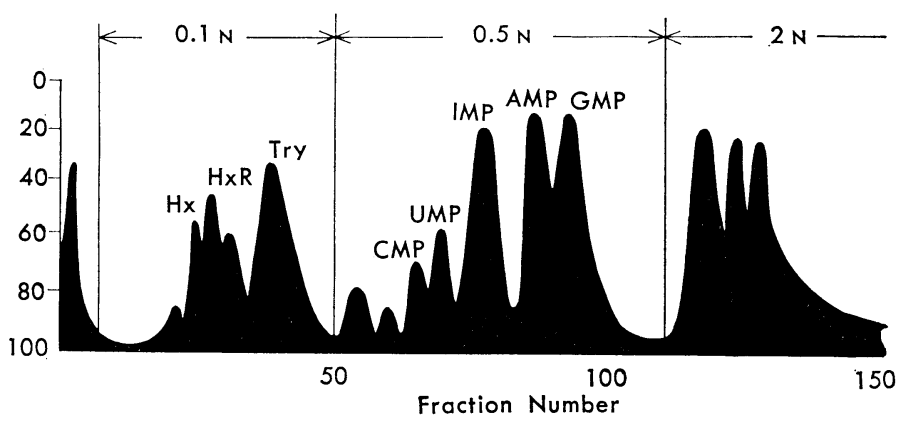

Fig. 8. UV-absorbing substance accumulated by No. 6 grown on $100 \mu \mathrm{g} /$ $\mathrm{ml}$ of adenine.

Supernatant of broth ( $\mathrm{pH} 9.6$ ), 3 to $4 \mathrm{ml}$, was chromatographed on a column $(7 \times 1.4 \mathrm{~cm})$ containing Dowex- $1 \mathrm{X} 8$ ion-exchange resin (100 to 200 mesh, formate form) at a rate of $30 \mathrm{ml} / \mathrm{hr}$. The resin was washed with water and the column was eluted with gradient concentration $(0.1$ to $2 \mathrm{~N})$ of ammonium formate. UV-absorbance of each fraction was recorded at a wavelength of $253 \mathrm{~m} \mu$ by a Uvicord (LKB type 4701, Sweden). Each fraction contained $\mu$ moles of substance per $\mathrm{g}$ of wet weight of cells: $\mathrm{Hx}, 15$; HxR, 12; CMP, 13; UMP, 20; IMP, 50; AMP, 69; GMP, 71. 


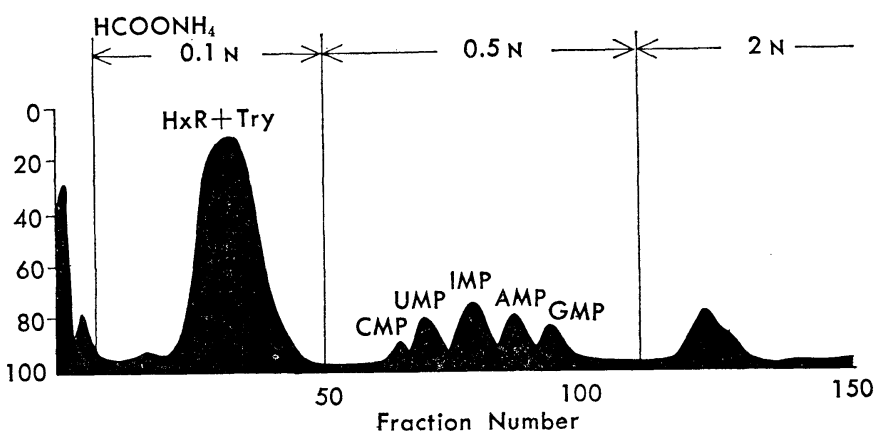

Fig. 9. UV-absorbing substance accumulated by No. 6 grown on 180 $\mu \mathrm{g} / \mathrm{ml}$ of adenine.

$\begin{array}{lcc}\text { No. } 6 & \mu \text { moles/g cell } & \text { No. } 93 \\ \text { HxR } & 283 & 1238 \\ \text { CMP } & 20 & - \\ \text { UMP } & 12 & - \\ \text { IMP } & 32 & <0.1 \\ \text { AMP } & 8 & - \\ \text { GMP } & 14 & -\end{array}$

\section{DISCUSSION}

The isolation of mutants devoid of 5 -nucleotide-degrading ability from Bacillus subtilis in an attempt to obtain some strains characterized by an increased accumulation of $5^{\prime}$-IMP have been reported by a few workers (30, 31). These results, however, were not necessarily satisfactory with respect to a marked increase in the accumulation of nucleotide. Fujimoto et al. (31) isolated two mutant strains devoid of 5'-nucleotide-degrading ability, A-1 and R-42, from $B$. subtilis 1145-2-83, which produced a significant amount of inosine extracellularly. These mutants were found to accumulate only a small amount of $5^{\prime}$-IMP, $5^{\prime}$-GMP, and a large amount of inosine as the parent strain did. They postulated that a large amount of $5^{\prime}$-IMP and $5^{\prime}$-GMP may be expected to be accumulated by the mutant whose cellular 5 '-nucleotidase is lower than that of A-1 or R-42. On the other hand, Momose et al. (30) suggested that the defect of nucleotide-degrading activity is favorable for the reservation of the preformed nucleotides in the culture, but unfavorable for the de novo synthesis or excretion of nucleotides.

Our present investigation seems to agree with the latter suggestion, since No. 6, the mutant devoid of $5^{\prime}$-nucleotide-degrading ability, became fragile and sensitive to adenine content in the medium. In No. 6 , high concentration of more than $500 \mu \mathrm{g} / \mathrm{ml}$ of adenine inhibited the early stage of growth, whereas the concentration of less than $180 \mu \mathrm{g} / \mathrm{ml}$ of adenine maintained only a short period of maximum growth followed by a marked cell lysis. These phenomena were peculiar not only to the mutant devoid of $5^{\prime}$ - 
nucleotide-degrading ability but also to the mutant less active or even inactive in alkaline phosphatase prepared by UV-irradiation in our laboratory. This remarkable change in characteristics is probably correlated in some way to phosphatase activities.

When $100 \mu \mathrm{g} / \mathrm{ml}$ of adenine was present in the medium, nucleotides were excreted extracellularly by No. 6 and the excretion ceased with the cessation of RNA degradation (Fig. 8). By contrast, in the presence of $180 \mu \mathrm{g} / \mathrm{ml}$ of adenine, inosine was accumulated in medium without an appreciable excretion of nucleotides, and the accumulation of inosine continued even after the cessation of RNA breakdown (Fig. 9). These results suggest that nucleotides and inosine are excreted independently by some different mechanisms.

Assuming that the high phosphate concentration in the medium has no influence on various activities of viable cells intracellularly, IMP synthesized de novo in viable cells of No. 6 is considered to be decomposed mostly to inosine by the intracellular alkaline phosphatase and inosine may be excreted into the medium. However, as soon as cell lysis occurs accompanied with the concomitant degradation of RNA, the activity of alkaline phosphatase liberated may be inhibited by a high concentration of phosphate, and thus nucleotides in medium may remain undegraded. Therefore, the extracellular nucleotides seem to be the degradation product of RNA and the extracellular inosine to be derived from IMP synthesized de novo in viable cells.

In selecting a certain strain for the industrial purpose of nucleotide fermentation, there may be several ways of approach, for example, (1) induction of mutation of the selected wild strains should be simple and easy, (2) selection of strains excreting comparatively larger amount of purine and pyrimidine derivatives without strongly regulated by the feedback mechanism, and (3) selection of strains excreting only nucleotides without accompanied degradation by nucleotidase. First, we selected Bacillus subtilis 209-4 as the parent strain based mainly on the principles (1) and (2), because we presumed that it might be possible to repress the phosphatase activities and to change bases and nucleosides into their nucleotides. However, inhibition of phosphatase activity of the adenineless mutant No. 93 was found to bring about unexpected lysis of cells. Therefore, the selection of mutants by the third principle may be worth referring to.

\section{REFERENCES}

1) H. K. Mitchell and J. F. Nyc: J. Am. Chem. Soc., 69, 674 (1947).

2) H. K. Mitchell, M. B. Houlahan and J. F. Nyc: J. Biol. Chem., 172, 525 (1948).

3) D. Billen, B. L. Strehler, G. E. Stapleton and E. Brigham: Arch. Biochem. Biophys., 43, 1 (1953).

4) B. Magasanik and M. S. Brooke: J. Biol. Chem., 206, 83 (1954).

5) J. S. Gots and S. H. Love: J. Biol. Chem., 210, 395 (1954).

6) A. G. Moat, C. N. Wilkins, Jr. and H. Friedman: J. Biol. Chem., 223, 985 
(1956).

7) C. W. H. Partridge and N. H. Griles: Arch. Biochem. Biophys., 67, 237 (1957).

8) R. E. HandschmaCkER: Nature, 182, 1090 (1958).

9) J. Skoda and F. Sorm: Biochem. Biophys. Acta, 28, 659 (1958).

10) H. Friedman and A. G. Moat: Arch. Biochem. Biophys., 78, 146 (1958).

11) J. L. Strominger: J. Biol. Chem., 234, 1520 (1959).

12) J. L. Strominger and R. H. Threnn: Biochem. Biophys. Acta, 36, 83 (1959).

13) H. Rотн, H. Amos and B. D. Davis: Biochem. Biophys. Acta, 37, 398 (1960).

14) C. L. Rosano, R. A. Peabody and C. Hurwitz: Biochem. Biophys. Acta, 37, 380 (1960).

15) N. Okabayashi and E. Masuo: Chem. Pharm. Bull. (Tokyo), 8, 370, 1084 (1960).

16) K. Uchida, A. Kuninaka, H. Yoshino and M. Kibi: Agr. Biol. Chem. (Tokyo), 25, 804 (1961).

17) T. Shiro: Agr. Biol. Chem. (Tokyo), 25, 350 (1961).

18) H. Sugrmoto, T. Iwasa and J. Ishiyama: J. Agr. Chem. Soc. Japan, 36, 690 696 (1962).

19) T. Shiro: Agr. Biol. Chem. (Tokyo), 25, 75 (1962).

20) R. Aoki, H. Momose, Y. Kondo, N. Muramatsu and Y. Tsuchiya: J. Gen. Appl. Microbiol., 9, 387 (1963).

21) K. OGata: Amino Acids, 8, 1 (1963).

22) K. Arima, T. Fukami, M. Fujiwara, M. Yokota and G. Tamura: J. Agr. Chem. Soc. Japan, 37, 453 (1963).

23) T. Fukami, H. Imanaka, M. Yokota, M. Fujiwara, G. Tamura and K. Arima: J. Agr. Chem. Soc. Japan, 37, 502 (1963).

24) M. Fujiwara, H. Nakamura, S. Y. Chu, T. Yamamoto, T. Fukami, G. Tamura and K. ARima: Amino Acid and Nucleic Acid, 8, 110 (1963).

25) S. Kinoshita: J. Fermentation Association Japan, 22, 1 (1964).

26) K. Nakayama, T. Suzuki, Z. Sato and S. Kinoshita: Amino Acid and Nucleic Acid, 9, 7 (1964).

27) M. Misawa, T. Nara, K. Udagawa, S. Abe and S. Kinoshita: Amino Acid and Nucleic Acid, 9, 14, 18 (1964).

28) K. Nakayama, T. Suzuki, Z. Sato and S. Kinoshita: J. Gen. Appl. Microbiol., 10, 133 (1964).

29) J. Lederberg and E. M. Lederberg: J. Bacteriol., 63, 399 (1952).

30) H. Momose, H. Nishikawa and N. Katsuya: J. Gen. Appl. Microbiol., 10, 343 (1964).

31) M. Fujimoto and K. Uchida: Agr. Biol. Chem. (Tokyo), 29, 249 (1965).

32) E. G. Gollub and J. S. Gots: J. Bacteriol., 78, 320 (1959).

$33)$ M. Nakamura: J. Agr. Chem. Soc. Japan, 24, 1 (1950). 